\title{
PART 7. PECULIARITIES OF THE CONFESSIONAL SITUATION IN TRANSCARPATHIA: HISTORY AND MODERNITY
}

The problem of state-church relations in Ukraine is being researched by many scientists. In Ukraine, the church and the state are separated from each other. But the development of state-church relations in the country was not easy. The situation of the church in the Soviet period was especially difficult. The problem of relations between the state authorities and religious organizations relates to current topics of modern Political Science. They have always been extremely important, but apparently no one will dispute that these issues are a hundred times more important for the present Ukraine and Transcarpathia itself. The Ukrainian state and the Ukrainian church have been inseparable in their history. With the adoption of Christianity by Ukraine, they exerted a mutual influence on each other: the state on the church and the church on the state.

Our people adopted Christianity in their own way after being baptized by Kniaz Volodymyr in 988. With the adoption of Christianity in Ukraine, a permanent organization of church management, called the Metropolis, centered in Kyiv, emerged. The first metropolitan came here, his successors also stayed here. At that time it was the church of the whole state of Kniaz, but it was most closely connected with the Ukrainian land and with our ancestors who lived on it. The Metropolis of Kyiv became the church of the exclusively Ukrainian and Byelorussian peoples, when the Moscow church arbitrarily (without the consent of Constantinople) put its own metropolitan in 1448 and thus separated from the mother-church in Kyiv. And 10 years later, the Moscow Council formalized this act of separatism. This act of arbitrary proclamation of autocephaly was distinctly non-canonical, but it was not disputed because of the political power of the Moscow State of that time.

The Metropolis of Kyiv has constantntly remained a church of the Ukrainian people throughout the thousands of years of its existence, which is why it, and with good reason, bears the name of the Ukrainian Orthodox Church. The Council of Kyiv in 1621, convened during the difficult struggle of the Orthodox Ukrainians with the Union, confirmed this view and went further, linking the beginnings of the Orthodox Church in Ukraine with the gospel of Apostle Andrew the First-Called. The resolution of the Council stated: "St. Andrew the Apostle was the first Archbishop of Constantinople, the Universal Patriarch and the Apostle of Ukraine; his feet stood on the mountains of Kyiv, and his eyes saw Ukraine, and his mouth blessed, and he 
planted the seeds of faith in us. Truly Ukraine is not smaller than other Eastern nations, because the apostle preached in it" ${ }^{373}$.

In the context of this study, it is very important to emphasize that from the very beginning of the formation of a church in Ukraine at the initiative of the state authorities, there was a close union between the church and the state. The state helped the church of Christ, and the church, for its part, cared about the authority of the state power among the people and about the moral influence of Christian ideals on the power. The chronicle retained the words of one of the metropolitans to Kniaz of Kyiv: "Kniaz! We are set in the land of Rus by God to keep you from bloodshed"

For seven centuries the Orthodox Church in Ukraine lived an independent life, bound only by the formal subordination to the Mother Church in Constantinople, from which it received the faith of Christ.

The synodal period of the history of the Russian Church, which lasted for 197 years (1721-1918) and brought complete enslavement to the Ukrainian church, was grossly non-canonical. Experts in the field of ecclesiastical law have repeatedly asked the question whether this Russian synodal church was canonical and solved it negatively - it was not canonical ${ }^{375}$. And if so, the whole activity of this church, including all its violence against the Ukrainian church, was not canonical and legal.

From an independent, highly developed, closely aligned with the people, the original Metropolis of Kyiv, the tsars of Moscow and their church quickly made it "non-personal". Despite the promises of widespread autonomy, given to the Orthodox Church in Ukraine during the change of jurisdiction, Moscow was quick to liquidate its independence and identity. The Metropolis of Kyiv was transformed - first practically, and then formally - into an ordinary eparchy of the Russian Orthodox Church. An immemorial in Ukraine practice of selecting metropolitan and bishops by councils was abolished: candidates for the vacant bishop's chairs were appointed by the Holy Synod and approved by the tsar. Since 1799 there have been no Ukrainians on the Kyiv Metropolitan throne ${ }^{376}$.

As a result, Moscow's "Caesarepapism" ended with the proclamation of the tsar as head of the church.

373 Огієнко І. Українська церква: Нариси з історії Української православної церкви. У 2-х т. Т. 1.147 с.; Т. 2. 418 с. К.: Україна, 1993. С. 8.

374 Слобідський Серафим, протоієрей. Закон Божий: Підручник для сімї та школи / Видання 3-є. К.: Видавничий відділ УПЦКП, 2004. С. 368.

375 Огієнко І. Українська церква: Нариси з історії Української православної церкви. У 2-х т. Т. 2. К.: Україна, 1993. С. 203, 212.

376 Воронин О. О. Автокефалія Православної Церкви. Кенсінгтон: Воскресіння, 1990. C. 26 . 
In Ukraine, it was forbidden to print church books other than those published in Russia. In the liturgy it was ordered to use the Russian pronunciation; the Russian Orthodox Church keeps this practice of Russification in Ukraine (except Galicia) and Belarus to this day. It was forbidden to preach in Ukrainian. Moscow continued to be disrespectful of preaching, and if the priest wanted to preach, he could do so only in a foreign to people language - in Russian ${ }^{377}$.

In XIX century the leveling of the Orthodox Church in Ukraine has accelerated. Priests, whom in Ukraine at the end XIX century were about 12,000, had to serve to a case of Russification. The eparchial bishops completed their administration with Russians or russified Ukrainians who were spiritually close to them. The Russians were also appointed as priests into larger and more important churches. There were people from Russia in many Ukrainian parishes, people who had nothing in common either in language, culture or spirit with the people they were supposed to serve. At the same time, talented priests from Ukraine were being sent to non-Russian peoples, conquered by the tsarist troops, to take part in their Russification"378. That is, Ukraine's "mortification" policy was paired with the final "mortification" of the Ukrainian National Church until its total decline.

Scientists highlight the following essential features inherent in statechurch relations in Ukraine during XVIII - XX centuries: statism of the church at all levels, transforming it into a component of the state executive mechanism with the status of a spiritual ministry; fulfillment by the church of a number of state and other non-church functions; actual loss by the church of independence from the state structures, its forced apologetic role for autocratic actions; proclamation of the autocratic-Russian version of the Orthodox Church as dominant; state policy of identification of Orthodoxy with the Russian nation; the legal inferiority of other nations and religions, etc $^{379}$.

The question of restoration of the independent Ukrainian Orthodox Church became relevant again in 1917, when tsar's regime was overthrown and the flames of the national movement erupted in Ukraine. The demands for the independence of church and religious life, the Ukrainianization of the church, the restoration of its cathedral system, and "exclusion of the

377 Слобідський Серафим, протоієрей. Закон Божий: Підручник для сімї та школи / Видання 3-є. К.: Видавничий відділ УПЦКП, 2004. С. 411-413.

${ }^{378}$ Слобідський Серафим, протоієрей. Закон Божий: Підручник для сімї та школи / Видання 3-є. К.: Видавничий відділ УПЦКП, 2004. С. 413.

379 Академічне релігієзнавство: Підручник / Під редакцією А. Колодного. К.: Світ Знань, 2000. С. 607. 
Russians on the episcopal chairs" were expressed at eparchial councils and other forums throughout Ukraine. At the end of 1917 an All-Ukrainian Church Cathedral was created to convene an All-Ukrainian Church Council. The main purpose was clearly and unambiguously stated in the message of the organizing committee of the council to the Ukrainian people: "Free Ukrainian people! ... You must immediately assemble your All-Ukrainian Orthodox Council of the clergy and laity and restore with its help the ancient independence of the Ukrainian Church, approved by the Treaty of Pereyaslav and illegally destroyed by the Moscow state!"380.

The awareness of the need for independence of the Ukrainian Orthodox Church was so widespread by the time of the convocation of the first AllUkrainian Orthodox Council in October 1921 that the issue of autocephaly was not even discussed at this historic Council. The canons, adopted be the Council, solemnly state: "The Ukrainian Orthodox Church, which forcibly and uncannily was deprived of autocephaly by the tsarist authorities, and which has morally and canonically always remained autocephalous, and by the decision of the All-Ukrainian Orthodox Council of May 5, 1920, has completely restored its autocephaly, it is autocephalous, it is not subject to any spiritual government of other Orthodox Churches, and itself commits its church life under the guidance of the Holy Spirit. The Ukrainian Orthodox Church, as an autocephalous one, is a free member of the World Cathedral Apostolic Orthodox Church and remains in unbroken fraternal unity with all the Orthodox churches" ${ }^{381}$. The Council decided to recognize as an immoral and anti-canonical act the forcible subjugation of the Ukrainian church to Moscow Patriarchate, which destroyed the spirit of its free creativity. "It was not only a hard violation of the canons... but also a violation of the very spirit of Christ's doctrine of love, equality and brotherhood"382 - declared the All-Ukrainian Orthodox Church Council in its appeal to the clergy of Ukraine in December 1921. The only possible way for the Ukrainian Orthodox Church was a way of completely independent life, free from any subjection, and it chose this way.

The communist regime quickly realized that the spiritual and moral power and nation-unifying influence of the independent Ukrainian Church on the people was dangerous to its purpose - to create a society without God, Christian morality and national consciousness. Autocephaly became, in the eyes of the authorities, tantamount to nationalism and separatism,

\footnotetext{
${ }^{380}$ Історія релігій в Україні: в 10 т. / А. Колодний, Р. Крижанівський. Т. 10. Релігія і церква років незалежності України. Київ - Дрогобич: Коло, 2003. С. 408-409.

${ }^{381}$ Історія релігій в Україні: в 10 т. / А. Колодний, Р. Крижанівський. Т. 10. Релігія і церква років незалежності України. Київ - Дрогобич: Коло, 2003. С. 136-137.

${ }^{382}$ Ibid. C. 137.
} 
"counter-revolution" and "petliurism". In 1930 during the fabricated trial against the Union for the Liberation of Ukraine (non-existent organization), the whole Ukrainian Autocephalous Orthodox Church was blamed in connection with the anti-Soviet activity. By 1937 the bishopry of the church, almost all the clergy were destroyed. Even the believers, who actively supported the autocephalous church in Ukraine, did not miss the "punishing sword of the revolution". On November 27, 1937 Metropolitan Vasyl Lypkivsky was $\operatorname{shot}^{383}$.

From this it follows that the Ukrainian church and religion were for the Communists almost the greatest enemy, greater than Christianity of the first centuries was for the authorities of that times. The anti-Church hysteria in the USSR caused the proclamation in September 1937 by the Central Committee of the Communist Party of the "godless five-year plan", during which religion and church had to be "destroyed".

Destroyed during Stalin's terror, the Ukrainian Autocephalous Orthodox Church was reborn during World War II. It was reborn spontaneously by the will of the people, who, despite two decades of cruel persecution, did not lose faith in God and devotion to their native church. In the summer of 1942 more than a thousand Ukrainian Orthodox parishes were established in Eastern Ukraine ${ }^{384}$. And there would be even more of them if oppression from the side of the invaders did not increase. More than 100 Ukrainian Orthodox priests and clergymen became victims of German terror. The Germans only in Volyn burned at least 14 villages and 17 churches, in some cases with people locked inside ${ }^{385}$.

After the return of the Soviet power to Ukraine in 1943-1944, the Russian Orthodox Church, headed by the Moscow Patriarchate, completely ruled it.

The first victim of the Bolshevik-Stalin's political genocide was the Ukrainian Greek Catholic Church. The blow first fell to the bishopric, without which the church cannot exist. On April 11, 1945 Metropolitan J. Slipyi was arrested in Lviv, Bishop G. Khomyshyn - in Stanislav (now Ivano-Frankivsk), and Bishop J. Kotsylovsky - in Peremyshl (now Przemysl, Poland) without any protest from the Polish authorities. They were all convicted. Except for Metropolitan J. Slipyi, who had been tortured in prison and exiled for 18 years, none of them returned to freedom.

\footnotetext{
${ }^{383}$ Гудима А. М. Релігієзнавство: Підручник. Тернопіль: Укрмедкнига, 2002. С. 194.

${ }^{384}$ Власовський І. Нарис історії Української Православної Церкви. Нью-Йорк: Саунд Баунд Брук, 1966. С. 234-235.

385 Власовський I. 10 літ тому. Український православний календар на 1953 рік. Видавництво Української Православної Церкви в США. С. 98-99.
} 
Now it is the turn for the church itself. Under the direct pressure of the authorities, a so-called "council" was convened in Lviv on March 8-10, 1946, and 214 priests and 19 laymen came to it, while being selected in advance. The content of its "work" was limited to the urgent solution of two major issues: the cutting of connections with Rome and the transition of the church under the authority of the Moscow Patriarch. From the point of view of the canon law of both the Catholic and Orthodox churches, this council and the synod of the Orthodox Church were completely illegal acts. There were no Catholic bishops at the synod, as they were all imprisoned. The Orthodox Church had no right to convene a synod of the existing Ukrainian Greek Catholic Church. But for the Moscow patriarchate and for the Soviet regime, the issue of legality was of no importance, since they had no respect for canon law ${ }^{386}$. Thus, Lviv Council in 1946 is not only a tragic landmark in the history of the Greek Catholic Church in Ukraine. It is also a tragedy of the Orthodox Church in general, since it, in the person of the Moscow Patriarchate, was given by a totalitarian regime a role of a burier of another church.

In 1949 the Soviet government liquidated the Ukrainian Greek Catholic (Uniate) Church in Carpathian Ukraine, abolishing the Union of Uzhgorod of 1646. Carpathian Ukraine, which was a part of the Czech-Slovak Republic before the war, was incorporated into the USSR in 1945. Transcarpathian Bishop Theodore Romzha died in November 1947 under mysterious circumstances. The Bolsheviks set up an accident, but when the bishop survived, he was poisoned in a hospital ${ }^{387}$.

Thus, after the forcible liquidation of the Greek Catholic Church in 19461947, the Moscow Patriarchate took control over all eparchies and parishes in Western Ukraine. With a complete monopoly of church activity in Ukraine, the traditionally chauvinistic Russian Orthodox Church has pursued a consistent policy of total denationalization of church life through the decades since World War II.

The Orthodox Church in Ukraine was fully subordinated to Moscow. The Bishops of the Eparchy in Ukraine were appointed by the Holy Synod of the Moscow Patriarchal Church. All decisions about church life were made in Moscow. The name "Exarchate of Ukraine" practically meant only the territory in which the eparchies were located, which in no way differed from similar eparchies in the rest of the Soviet Union. Metropolitan of Kyiv and Halicia was not the first hierarch and spiritual leader of the original church -

386 Ленцик В. Українська Католицька Церква в Совєтському Союзі. Російщення України: Науково-популярний збірник. К.: Видання УККА, 1992. С. 19.

${ }^{387}$ Ibid. C. 194. 
he was, according to the Ukrainian diaspora writer and public figure O. Voronyn, the deputy of the church-enslaver in the church-colony.

Signs of easing tensions in state-church and especially state-Orthodox relations emerged only in the late 1980s. Religious communities gradually began to get out of party-state control and act independently.

In 1989 an autocephalous movement was revived in Ukraine. In early 1990 the All-Ukrainian Council of the Ukrainian Autocephalous Orthodox Church (UAOC), held in Kyiv, confirmed the fact of the UAOC's restoration and decided to establish its patriarchate. The first patriarch was elected Metropolitan of the Ukrainian Orthodox Church in the United States Mstyslav (Skrypnyk).

Seeking to limit the spread of the UAOC and taking into account the processes of national and religious revival in Ukraine, the leadership of the Russian Orthodox Church (ROC) has reorganized its structures in Ukraine. The Ukrainian Exarchate of the ROC was renamed into the Ukrainian Orthodox Church with the rights of autonomy. As a result, the Ukrainian Orthodox Church emerged, remaining part of the Moscow Patriarchate. Part of the Ukrainian clergy, led by Metropolitan Filaret, after the declaration of independence of Ukraine raised the question before the ROC leadership about full autocephaly. However, without obtaining consent, in 1992 it united with the UAOC and formed the Ukrainian Orthodox Church (UOC) of the Kyiv Patriarchate. However, a number of bishops of the UAOC did not support the new unification, and after the death of the head of the UOC of the Kyiv Patriarchate Mstyslav in 1993, they again proclaimed the UAOC, whose head was elected Patriarch Dimitri. In its turn, the Council of UOC of the Kyiv Patriarchate elected Metropolitan Volodymyr as the Patriarch of Kyiv and All Rus-Ukraine (1993-1995). After his death, Metropolitan Filaret, who was elected patriarch, headed the UOC of the Kyiv Patriarchate. Thus, there are currently three Orthodox churches in Ukraine - the UOC of the Kyiv Patriarchate, the UAOC and the UOC of the Moscow Patriarchate ${ }^{388}$.

Therefore, in the context of large-scale socio-political changes that took place in the USSR in the late 1980s and early 1990s, totalitarian Soviet policy on religion and church collapsed. On April 23, 1991 the Verkhovna Rada of Ukraine adopted the Law of Ukraine "On Freedom of Conscience and Religious Organizations", which significantly influenced the religious situation in Ukraine. This law defined the basic principles of state-church relations, the rights and obligations of the state in relation to believers and

${ }^{388}$ Стоцький Я. В. Релігійна ситуація в Україні: проблеми і тенденції розвитку (19881998). Тернопіль: Астон, 1999. С. 96. 
religious organizations, as well as believers and religious organizations in relation to the state.

Important was the consolidation at the legislative level of such provisions and principles as the separation of church (religious organizations) from the state and school from the church, equality of all religions, denominations and religious organizations before the law, equality of citizens regardless of their attitude to religion, prohibition of privileges or restrictions on the grounds of religious or other beliefs, the acquisition by a religious organization of the right of a juridical person, the protection by the state of the legal rights and interests of believers and religious organizations.

Each citizen was guaranteed the right of freedom of thought, which included the freedom to have, accept and change religion or belief of his choice, and the freedom to practice or not to practice any religion alone or with others, to serve religious cults, to openly express and to freely spread own religious or atheistic beliefs and act due to them.

The state did not interfere in the internal affairs and activities of religious organizations. Religious organizations, in turn, did not perform state functions.

Considering the difficult Soviet religious heritage, one of the tasks of the law was "overcoming the negative consequences of state policy on religion and the church" 389 .

Religious organizations were given the right to participate in public life, to be engaged in socially significant activities and to use mass-media just like public associations.

Citizens who worked in religious organizations and at enterprises, created by them, were subject to the laws of labor, taxation, state social insurance ${ }^{390}$.

After the proclamation of Ukraine's independence on August 24, 1991, it had new opportunities for defining and implementing its own religious policy, for the revival and development of religious church life, for the development of civilized relations between the state and the church.

The state's strategy for the full protection of religious rights and freedoms was further reflected in the Constitution of Ukraine (1996). Some theses contained in the Law of Ukraine "On Freedom of Conscience and Religious Organizations" (separation of the church from the state and school from the church, the right of freedom of conscience and religion, cases of its restriction, etc.) were enshrined at the constitutional level. Religious

389 Закон України «Про свободу совісті та релігійні організації». Відомості Верховної Ради УРСР (ВВР). № 25. ст. 10.

${ }^{390}$ Ibid. 
pluralism in Ukrainian society was defined by the constitutional formula "no religion can be recognized by the state as obligatory" "391. In the case when the performance of military duty contradicted the religious beliefs of the citizen, the Basic Law gave the right to replace it with an alternative (non-military) service ${ }^{392}$. The procedure of passing this service was determined by the Law of Ukraine "On Alternative (Non-Military) Service" ${ }^{393}$.

Considering the fact that Ukrainian society is multi-ethnical and multiconfessional, the state has assumed a constitutional obligation to promote the development of the religious identity of all indigenous peoples and national minorities of Ukraine. In order to avoid ethno-national and interconfessional conflicts, to ensure peace and harmony in Ukrainian society, the Constitution of Ukraine prohibited "the formation and activities of political parties and public organizations whose program purposes or actions are aimed at... inciting ethnic, racial, religious hatred"394.

Thus, the legal basis for the formation of such a model of state-church relations, which provided the granting of wide religious freedoms, appeared in Ukraine. Restrictions to the freedom of conscience and religion, to the serving of religious cults, religious activities were established only in the interests of public order, public health and moral, or protection of the rights and freedoms of others ${ }^{395}$.

Later, a number of sectoral legislative and other legal acts was adopted, which resulted in the creation of a legal system that comprehensively regulated the relations between the state and the church, the activities of religious organizations in various spheres of public life.

Thus, with Ukraine's independence, the former confrontational model of state-church relations was destroyed and the foundations for forming partnerships between the state and the church were laid.

Each religion was given the opportunity to openly declare about its existence, to carry out its religious and non-religious activities freely, to build its own infrastructure, to communicate freely with fellow believers abroad.

As we can see, Ukrainian society is characterized by confessional diversity, which is a manifestation of the real guarantee of the right to freedom of conscience and religion, as well as the principle of religious

\footnotetext{
${ }^{391}$ Конституція України. Відомості Верховної Ради України (ВВР). 1996. № 30. ст. 141.

${ }^{392}$ Ibid.

393 Закон України «Про альтернативну (невійськову) службу». Відомості Верховної Ради України (ВВР). 1992. № 15. ст. 188.

${ }^{394}$ Конституція України. Відомості Верховної Ради України (ВВР). 1996. № 30. ст. 141.

${ }^{395}$ Ibid.
} 
pluralism, enshrined in the Constitution of Ukraine and the Law of Ukraine "On Freedom of Conscience and Religious Organizations"396.

According to the information of the Department of Religions and Nationalities of the Ministry of Culture of Ukraine, which was presented in the Report on the Network of Churches and Religious Organizations in Ukraine as of 01.01.2019, religious differentiation in Ukraine is as follows:

- Number of religious communities: 35,162 ;

- Monasteries - 531, monks and nuns - 6794, missions - 368, fraternities 83 ;

- The clergy, including foreigners - 32619/918;

- Spiritual educational institutions - 204, incl. higher / secondary 136/68, listeners in them (day-time / part-time) - 7939/9947;

- Schools, incl. general education / Sunday - 13211 - 16/13195;

- Massmedia, incl. printed / audiovisual / electronic - 530 $341 / 22 / 167^{397}$.

At the same time, multi-confessionality of Ukrainian society causes competition between religions, which in the absence of a proper level of interfaith tolerance can cause tension in the society.

Nowadays, there is a confrontation between the Orthodox churches among themselves, between the Orthodox, on the one hand, and Roman and Greek Catholics, on the other, between the traditional religions and neoreligions. In these circumstances, a dialogue aimed at forming among believers of inter-confessional tolerance, the experience of foreign countries, where representatives of different religions peacefully exist, is relevant for Ukraine.

The level of inter-denominational confrontation could be significantly reduced by the proper provision of cult buildings for religious organizations. Today this need is satisfied for 67 percent. This situation does not remove from the agenda the issue of the return to religious ownership or use of all religious buildings that are still not being used for their intended purpose. At the same time problems of the alternate use of temples by various religious organizations and the new cult construction do not lose the relevance.

This also preserves some potential for conflict, the basis of which is the property issue, which is concerned with the lack of cult buildings for religious organizations (only 75.5\%). Their active construction and restoration of formerly unused temples over the past decades has greatly mitigated the problem. It should be emphasized that when joining the

\footnotetext{
396 Закон України «Про свободу совісті та релігійні організації». Відомості Верховної Ради УРСР (ВВР). № 25. ст. 10.

${ }^{397}$ Релігійно - інформаційна служба України. [Електронний ресурс] / Режим доступу: https://risu.org.ua/ua/index/resourses/statistics/ukr_2019/75410/
} 
Council of Europe, Ukraine has committed itself to restitution of its former church property. According to paragraph XI of the Conclusion No. 190 (1995) of the Parliamentary Assembly Council of Europe (PACE), Ukraine was advised to settle a "legal solution to the issue of the return of church property"398. PACE Recommendation No. 1556 (2002) of 24 April 2002 reminded Ukraine of the need to "guarantee to religious institutions whose property had been nationalized in the past, the restitution of that property in proper time or, if that is not possible, a fair compensation" ${ }^{399}$.

It should also be noted that much has already been done in Ukraine in this direction: by 2008, about 3,6 thousand religious buildings and over 12 thousand items of church use were returned to the church or transferred for use $\mathrm{s}^{400}$. The church remains the only institution to which restitution is applied. Many legal acts have been adopted to complete the restitution of church property. Draft of the Law of Ukraine "On Return of Religious Property to Religious Organizations" was developed" $"$.

The experience of the countries of Central and Eastern Europe, which have solved this problem at the state level almost completely, is illustrative in this respect.

In contrast to the post-Soviet countries, the countries of Central and Eastern Europe have clearly defined the range of objects and the ways of their return to the church. Each country of the post-socialist space has developed its own strategy of restitution of church property, which is understandable due to different religious traditions and different starting conditions. The example of the countries of Central and Eastern Europe regarding the return of property to religious organizations shows that this process is painful for both the church and the state. It is difficult to set similar rules for cases requiring atypical decisions. At the same time, the experience of the countries of the Visegrad Four shows that in order to complete the restitution of church property, it is necessary to carry out a complete inventory of religious buildings, to create a single register of

398 Висновок ПАРС № 190 (1995) щодо вступу України до Ради Свропи. Страсбург. 1995. 25 вересня. Реституція иерковного майна: міжнародний та вітчизняний досвід: збірник наукових матеріалів. К., 2007. С. 65.

${ }^{399}$ Релігія та зміни в у Центральній та Східній Європі: Рекомендація ПАРЄ № 1556 (2002). Реституція иерковного майна: міжнародний та вітчизняний досвід: збірник наукових матеріалів. К., 2007. С. 65.

${ }^{400}$ Новиченко М. Р. Повернення церковного майна як пріоритет державної політики щодо релігії та церкви. Пріоритети державної політики в галузі свободи совісті: иляхи реалізаиіï. К.: Світ Знань, 2007. С. 69-70.

${ }^{401}$ Про звернення культового майна релігійним організаціям: Проект Закону України. Реституція церковного майна: міжнародний та вітчизняний досвід: збірник наукових матеріалів. К., 2007. С. 76-80. 
objects that have to be returned to the church. It is important to provide the sources and procedures for financial compensation to recover damages to persons in connection with the return procedures.

At this stage of development one of the peculiarities of the contemporary religious situation in Ukraine is confessional regionalism, which is based on the different concentration of certain religions in individual regions. Although all regions of Ukraine are largely multi-denominational, some of them are clearly dominated by individual religious organizations.

The struggle for temples in some towns of Ukraine often turns into open conflicts, clashes between believers. If the Ukrainian Orthodox Church of the Kyiv Patriarchate considers this process quite natural and qualifies it as the "unification from below" then the Ukrainian Orthodox Church of the Moscow Patriarchate qualifies it as "seizing temples". With the direct support of the Russian Orthodox Church, it tries to use all the possibilities to "protect canonical Orthodoxy", to prevent it from leaving parishes, temples and property.

Local authorities, citing the separation of the church and the state, try not to interfere in this process. In addition, according to an Internet poll, 74,7 percent of respondents said that a parish council together with a priest and parishioners should determine the religious affiliation of the temple ${ }^{402}$.

An important historical process, witnessed by Ukraine, is the granting of autocephaly to the Ukrainian Orthodox Church. This process is a consequence of the centuries-long struggle of the Ukrainian people for their spiritual independence, Transcarpathia also was not left aside this process.

Transcarpathia is a special territory in which various religious denominations exist in mutual understanding. It is a historical and ethnographic region, where for centuries representatives of different peoples and denominations have interacted in the stripe of ethnic and political borderline with Romanians, Hungarians, Slovaks and Poles. The religious and ecclesiastical life of the region has its own peculiarities, because not only the political and economic interests but also the religious interests of the neighboring countries are intertwined here. Many religious confessions, directions, movements are registered in the territory of Transcarpathia, among them:

1. Ukrainian Orthodox Church of KP, MP.

2. Greek Catholic Church.

3. Jehovah's Witnesses (division into Ukrainian, Hungarian, Romanian districts).

402 Церква. Режим доступу: http://www.religion.in.ua/news/ukrainian_news/30152 uapcprijnyalausvoyuyurisdikciyumonastirupcmp. html. 
4. Transcarpathian Reformed Church (appeared in the land in the XVIXVII centuries. It operates autonomously, the center is in Berehovo).

5. Roman Catholic Church (Appearance at the end of XI century. It operates independently, center - Mukachevo).

6. Church of Evangelical Christians - Baptists.

7. Union of Christians of Evangelical Ukraine (Pentecostal).

8. Union of Evangelical Christians (Sabbatarians) (Appearing in 1940s, it operates autonomously).

9. Seventh-day Adventist Church (Appearance in 1912).

10. Church of Christians of the Seventh Day (Appearance in the early XX century).

11. Reformed Adventist Church (Appeared in 1914, center Oleksandrivka village).

12. Judaism. (Autonomous community, appeared in the XVII century).

13. Union of Free Churches of Christians of Evangelical Ukraine.

14. Methodist Church (1920's).

15. Buddhists.

16. The Church of Jesus Christ of Latter-day Saints and others.

As of January 1, 2019 in Transcarpathia there are 1977 religious organizations of 37 denominations, movements and directions, 1860 communities, of them registered 1739 (invalid 13), of which 151 religious communities operate without registering their charter in accordance with part three of Chapter 8 Of the Law of Ukraine "On Freedom of Conscience and Religious Organizations", 7 spiritual educational institutions, 1076 schools, 1993 clergymen, 82 of which are foreigners (Table 1). 
Table 1

Report on the Network of Religious Organizations in Ukraine as of January 1, 2019

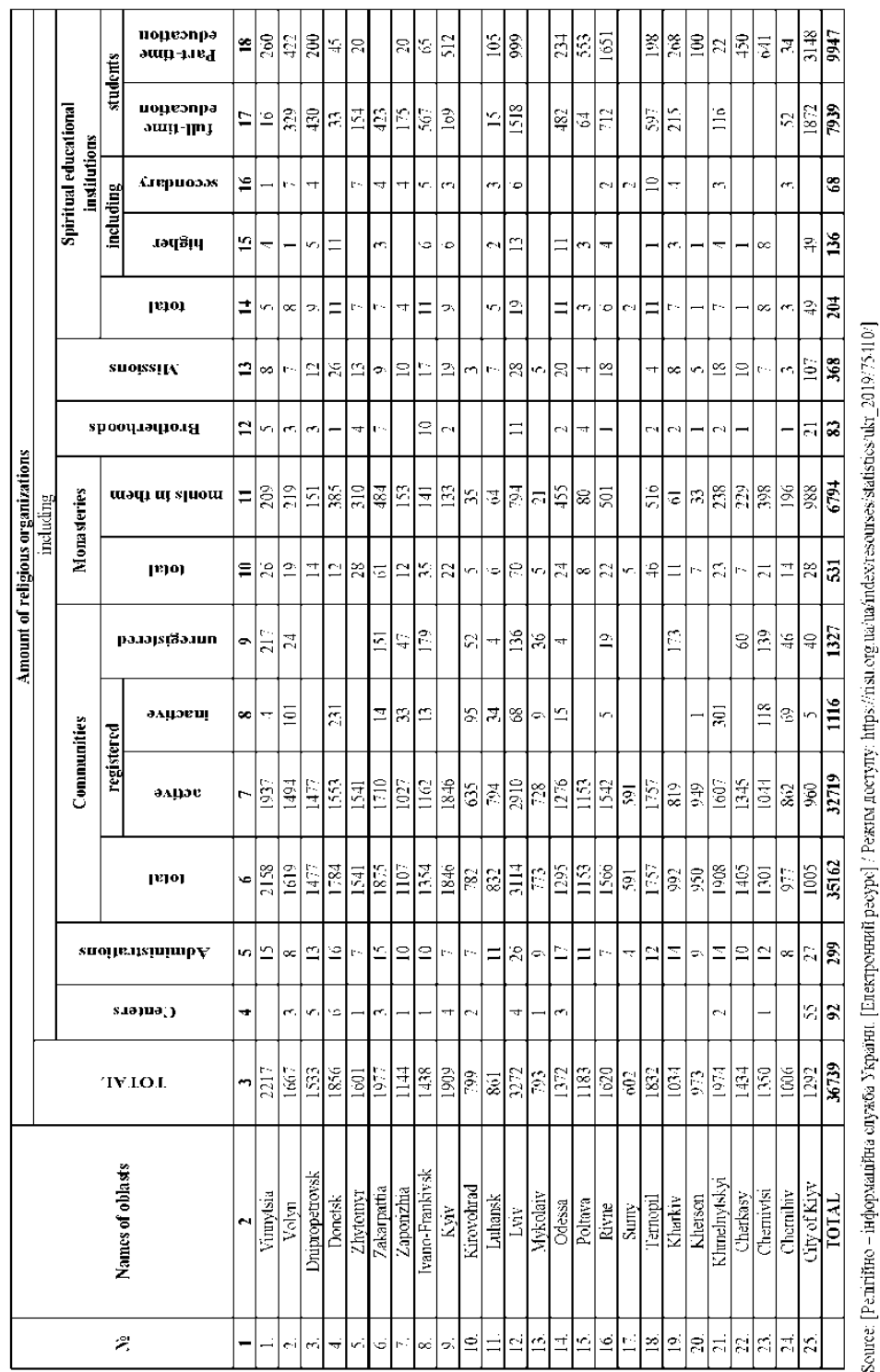


Table 1 (Continue)

Report on the Network of Religious Organizations in Ukraine as of January 1, 2019

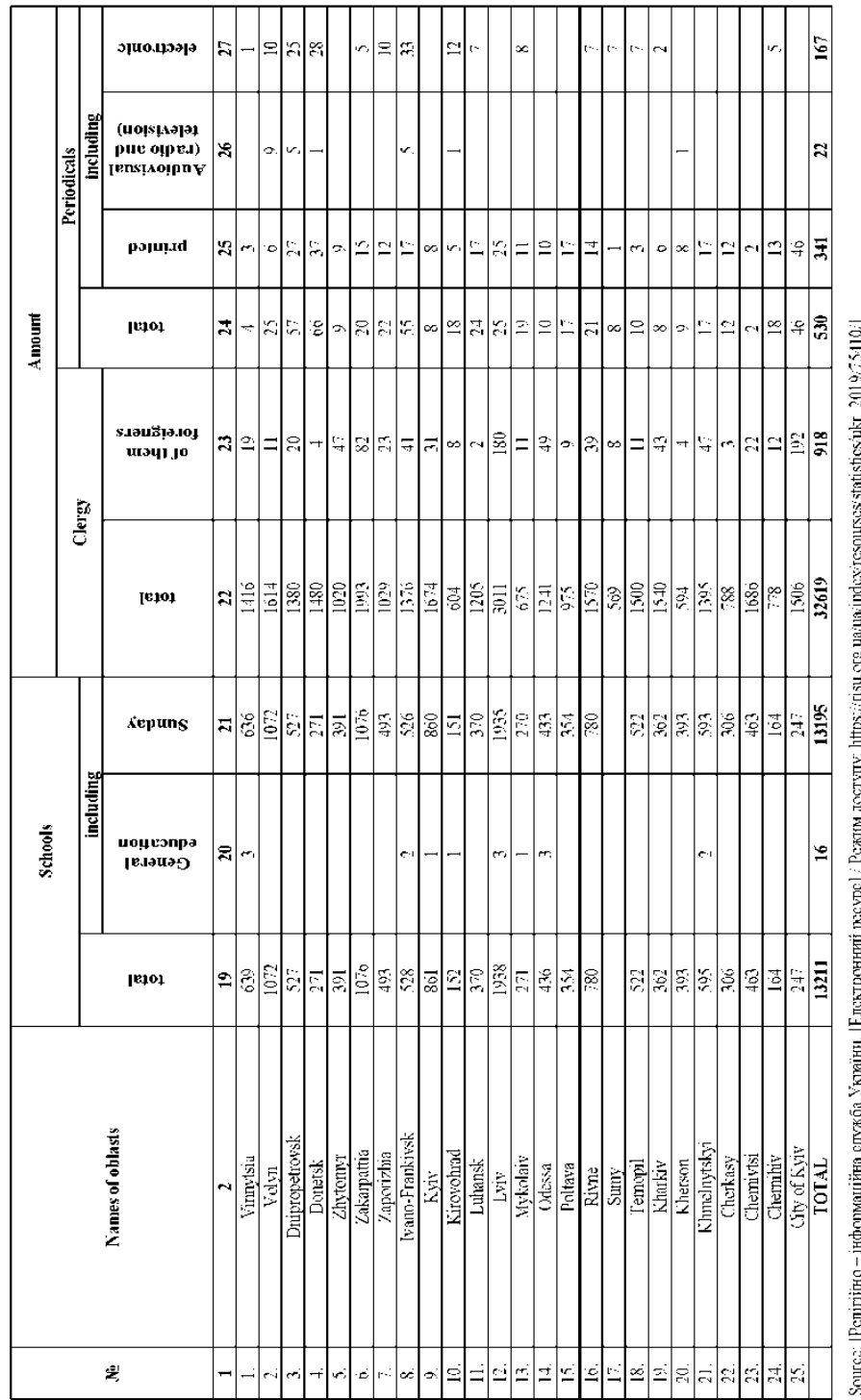


From Table 1. it is possible to analyze that as of January 1, 2019 in Transcarpathia there are:

- 1977 religious organizations of 37 denominations, movements and directions, of which 151 religious communities operate under part three of Chapter 8 of the Law of Ukraine "On Freedom of Conscience and Religious Organizations" - without registration of the charter;

-61 monastreies;

- 7 spiritual educational institutions;

-9 missionary communities;

- 7 religious brotherhoods, 3 centers and 15 administrations;

- there are 1,076 Sunday schools in religious communities. 1993 clergymen, 82 of whom are foreigners, perform church service ${ }^{403}$.

Believers meet their prayer needs in 1,602 worship buildings and worship apartments, of which 1,346 are temples and houses of worship, 101 are in use, and 155 have been adapted for worship.

During the period of independence from 1991 to 2018, 733 religious buildings were built by believers. During the period of $1992-2018,127$ religious objects (out of 281 identified objects of the former church property) were returned to the religious organizations of the region ${ }^{404}$.

The largest number of religious organizations has got the Ukrainian Orthodox Church -670 religious organizations. The second position is taken by the Mukachevo Greek Catholic Eparchy - 466 organizations. The Transcarpathian Reformed Church - 117 and the Mukachevo Diocese of the Roman Catholic Church - 102 religious organizations. The Transcarpathian Eparchy of the Ukrainian Orthodox Church of the Kyiv Patriarchate includes 54 religious communities and one monastery. The Ukrainian Autocephalous Orthodox Church in the region brings together 24 religious communities and a eparchial administration.

The number of registered Protestant religious associations includes 531 religious organizations. According to the registered charters, there are 14 Jewish religious communities, 6 other Orthodox religious communities, 2 Gentile communities, 1 - Buddhists, Muslims, the Krishna Consciousness Society and the Armenian Apostolic Church.

As for the general religious differentiation of the region. The most influential (in terms of authority and level of influence) and the largest (in terms of confessional structure) are the UOC and UOC of Kyiv Patriarchate. The UOC is dominant in all districts of the region, with the exception of the Berehovo district (where it takes approximately $17 \%$ of the total number of registered in the district.) (Table 2).

\footnotetext{
${ }^{403}$ Релігійно - інформаційна служба України. [Електронний ресурс] / Режим доступу: https://risu.org.ua/ua/index/resourses/statistics/ukr_2019/75410/

${ }^{404}$ Ibid.
} 
Table 2

\section{REPORT}

on the network of religious organizations in Ukraine as of January 1, 2019

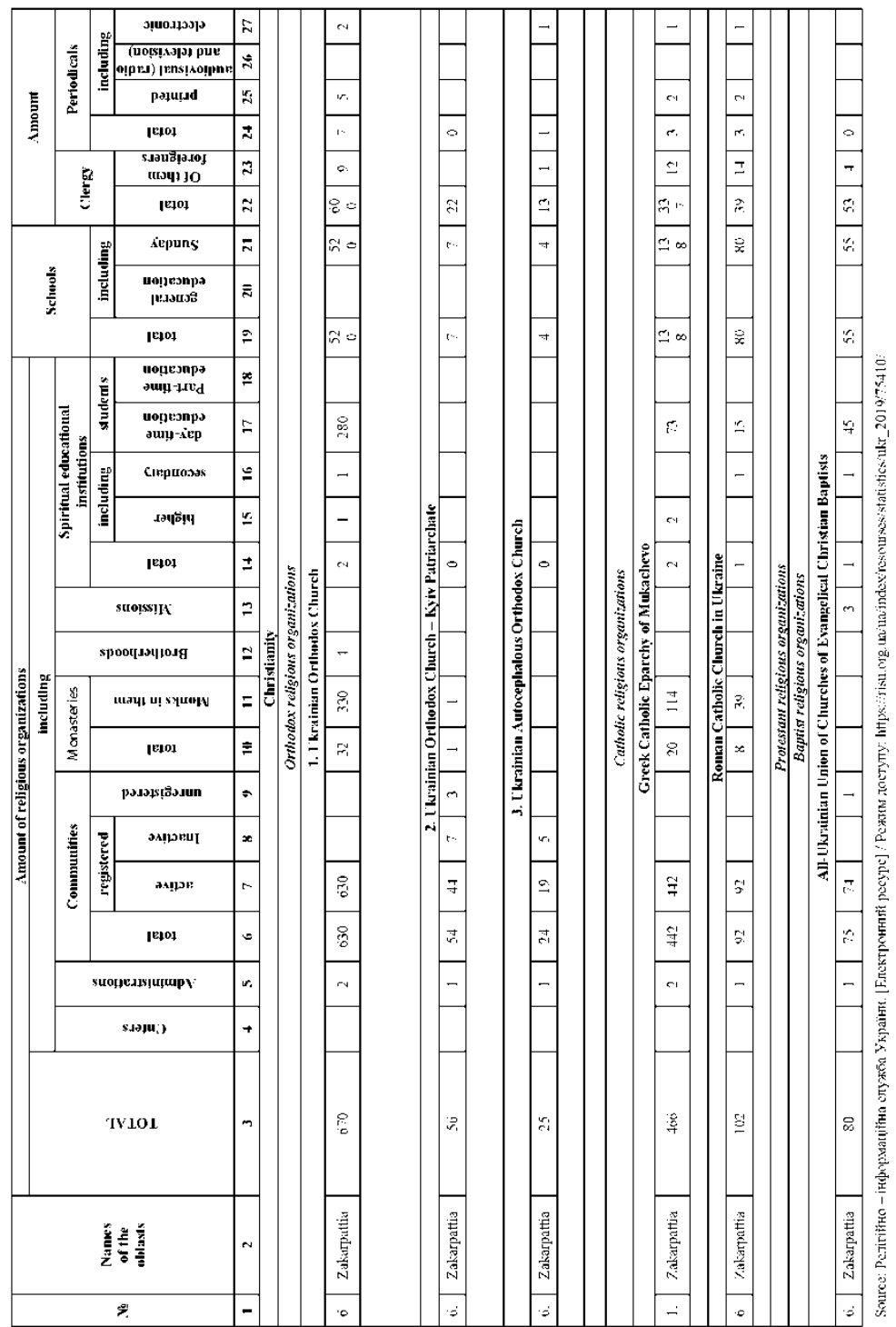


During the Soviet Union, the Orthodox Church in Ukraine was under the total control of the Communists. After January 22, 1946, when the Decree of the Presidium of the Supreme Soviet of the USSR approved the submission of the Presidium of the Supreme Soviet of the UkrSSR on the formation of the Zakarpattia oblast within the USSR. The resolution on the introduction of the legislation of the Ukrainian Soviet Socialist Republic on the territory of Zakarpattia oblast was adopted on January 25, 1946.

Thereby, "...the Constitution of the USSR of 1936 and the Constitution of the UkrSSR of 1937 came into force in Transcarpathia"405. And according to the legislation of the USSR, according to the Decree of the Council of People's Commissars "On Separation of the Church from the State and the School from the Church" of January 29, 1918 - the church was separated from the state in the Soviet Union.

But despite this, the Soviet leadership tried to control the activities of the churches and interfered with church life (a direct testimony to this was the murder of Bishop T. Romzha and the liquidation of the Greek Catholic Church.). It should be noted that the Orthodox Church in Transcarpathia was in especially difficult conditions under Stalinism in 1946-1953. Orthodox Christians had to adapt themselves to the existence in the atheist USSR. The activity of the church was under total control, because the activity of religious organizations was controlled by two structures in Transcarpathia:

- Council on the affairs of the Russian Orthodox Church;

- Council on Religious Cults ${ }^{406}$.

Catholicism in oblast is represented by the Greek Catholic Church and the Roman Catholic Church. Ukrainian Greek Catholic Church ranks second in the region after Orthodoxy. Founded in 1596, it is represented in Transcarpathia by the Eparchy of Mukachevo. At the end of the XI century a Roman Catholic Church appeared in Transcarpathia, now it is represented by the Mukachevo diocese in the region.

Acute conflicts between Orthodox and Greek Catholics do not arise nowadays, as it was during the communist regime, when state-makers tried to use the ancient disputes between Orthodox and Greek Catholics in the case of liquidation of the GCC in the Western Ukraine; conflicts between them were provoked by the central communist power, and they were mostly

${ }^{405}$ Макара М. П. Встановлення на Закарпатті Радянської політичної системи. Нариси icmopï Закарпаття. Т. ІІІ. (1946-1991). Ужгород: Госпрозрахунковий редакційновидавничий відділ у справах преси та інформації, 2003. С. 37.

406 Данилець Ю.В., Міщанин В.В. Православна церква на Закарпатті в часи «сталінщини (1946 - 1953 рр.). [Електронний ресурс] / Режим доступу: file:///C:/Users/home/Downloads/Nvuuist_2013_1_9\%20(1).pdf 
concerned with property $(1945-1946)^{407}$. Most often, conflicts occurred in villages where religious issues had not been resolved. "Every political regime pursued a church policy favorable to the ruling state for its approval in Transcarpathia. For this purpose, along with the use of interethnic contradictions, the emphasis was placed on interfaith differences..."408.

Protestant communities are also becoming widespread in Transcarpathia, but their part in different areas of the region is uneven. Despite the fact that in the Soviet times, after the creation in 1944 of the Council on Religious Cults at the Soviet People's Commissar of the USSR, led by I.V. Polyansky, the Soviet leadership ordered to establish the control and possibility of manipulation over Protestant communities, the Soviet leadership promoted the unification of Protestant denominations resulted in the formation of the Union of Baptist Christians, led by the All-Union Council of Evangelical Christians and Baptists. Joining this organization and registering gave virtually the only opportunity for these communities to exist ${ }^{409}$. At the present time, all Protestant movements act freely in the territory of Transcarpathia and have a moderate religious dialogue with other religious communities of the region.

The Reformed Church is also widespread in the land. It appeared in the XVI - XVII centuries - one of the Calvinist churches represented in Ukraine, the vast majority of believers in Transcarpathia are Hungarians, and the church operates in 8 districts $^{410}$. In Berehovo, Vynohradiv, Mukachevo, Uzhgorod and Khust districts of Transcarpathian region. It is a member of the Commonwealth of Reformed Churches of the Carpathian Basin.

The regional state administration, executive authorities and local selfgovernment are making efforts to return former religious buildings to Greek Catholic communities, to the religious communities of the Roman Catholic Church, Transcarpathian Reformed Church, Evangelical baptist-christians

407 Доповідні записки уповноваженого Ради у справах релігійних культів Петра Лінтура про релігійну політику на Закарпатті (1945 - 1946 рр.). [Електронний ресурс] / Режим доступу: https://www.pulib.sk/web/kniznica/elpub/dokument/Kocvar8/subor/ 05_Miscanin.pdf

${ }^{408}$ Макара М. Питання релігійної політики в діяльності Народної Ради Закарпатської України (XI. 1944-I.1946 рр.). Ужсгородській унії - 350 років: Матеріали міжнародних наукових конференцій (Ужгород, квітень 1996 р.). Ужгород, 1996. С. 127.

409 Закарпатська реформатська церква у перші повоєнні роки / I. В. Шерстюк. Історична пам'ять. 2012. Вип. 28. С. 86.

${ }^{410}$ Костащук I., Синько М. Релігійна сфера Закарпатської області. [Електронний pecypc] / Режим доступу: https://collectedpapers.com.ua/wp-content/uploads/2015/02/ 696_024_Kostaschuk_2.pdf 
and others. Religious organizations are provided with religious buildings for $90 \%$. They receive help in their connecting with associates abroad ${ }^{411}$.

In Transcarpathia, there is a high degree of trust to religious organizations, and in the region the state policy on religion and church, on protecting the rights and freedoms and keeping the right of the citizens to freely satisfy their needs will continue to be ensured.

Analyzing the inter-denominational relations in Transcarpathia, we can state the inter-denominational concord between the different churches, denominations and movements, which exist in Transcarpathia. There are many ecumenical churches and premises in the territory of the region, where priests of different denominations take turns in church service. And this does not lead to the rise of sharp debates and discussions among the confessional communities.

411 Резеш Й.Й. Про стан та тенденції розвитку релігійної ситуації, державно церковних відносин в Закарпатській обл. [Електронний ресурс] / Режим доступу: http://centerkyltyr.pp.ua/2018/05/05/1649/ 